\author{
Natalia Giza
}

Pedagogical University, Kraków

\title{
GETTING MARRIED IN TENAISSANCE ENGLAND AS PRESENTED IN THE CONDUCT LITERATURE FOR WOMEN
}

\begin{abstract}
There were two "career paths" open to Renaissance women in England — entering a monastery or getting married. With the introduction of reformation the first option vanished. Getting married opened varying possibilities. On one hand the contemporary promotion of marriage reinforced the patriarchal system of the society (a man is its head and the woman and children are his subjects). On the other, the idea of a "companionate marriage" allowing husbands and wives a certain degree of equality was formulated for the first time also by sixteenth-century thinkers. The traces of the Renaissance debate on which form of life is more pious and pleasing to God - celibate or married - can also be found in the conduct literature for women, on top of other advice referring to marriage.
\end{abstract}

Keywords: marriage in the sixteenth century, conduct books for women, Renaissance women, companionate marriage

Słowa kluczowe: małżeństwo w XVI wieku. Poradniki dla kobiet, kobiety w renesansie, małżeństwo partnerskie

Renaissance daughters were trained and educated with a view to becoming good wives, mothers and housewives. Conduct books, popular in the sixteenth century, dedicated to the fairer sex were there to help them attain desired qualities, practise virtues and avoid vices. They were addressed to women in general, regardless of their social status, because the examples they set were deeply rooted in the Christian tradition and should have been followed by everybody. Even the uneducated female members of the lower classes were advised to listen to the conduct books being read aloud to them as they could learn from them how to be chaste, silent and obedient — three major traits vital 
for a good Christian woman and necessary when looking for a good husband. Getting married was assumed to be the destiny of the majority of girls (apart from those who preferred or were made to prefer the convent), so the advice books of those times contained some useful guidelines on how to prepare themselves for the big day, which female qualities were sought after and which were seen as off-putting, what sort of men would make good husbands, how to organise the wedding reception, and what to expect once the marriage had been contracted. It should also be underlined that the body of "conduct literature", apart from the advice books written especially for women, also includes the texts such as sermons, prayers, poems or literary works which contain some sort of advice on how women could live a good life.

\section{Looking for the best spouse}

When a girl reached the marriageable age, it was their parents' duty to start looking for the best candidate. It was not clear when exactly the girl was ready to get married some claimed that once she turned 12 the girl was mature enough to become a wife (Barberino, 1842, p. 78), others warned that women who got married too early would bear "wicked children" (Minorta, cited in Chojnacki, 2000, p. 187). However, most suggested waiting until the girl was at least 17 or 18 because only then would she be able to give birth and nurture strong and healthy children (Marconville, 1573, p. 30a; Vives, 2000, p. 291).

Pre-arranged marriages for children or teenagers were still common in the sixteenth century but usually among the members of the upper classes who had to take into account the continuation of the family line, family alliances or economic reasons. (Stone, 1965, pp. 594-599) Marriages in the sixteenth-century England were contracted relatively late - for men it was 25-29 years of age (or even later) and for women 22-26 (Youings, 1984, pp. 361-369; Abbott, 1996, pp. 95-97; also: Stone, 1965, Appendix XXXIII, p. 792; Stone, 1977, pp. 46-50). However, the statistics often fail to depict the entirety of the problem, thus it can be assumed that the decision to marry off one's daughter was probably made individually and was adjusted to the current situation and needs.

The authors of the Renaissance conduct books were of the opinion that young, inexperienced girls were far better candidates for wives than, for example, widows because a young girl could faster and easier adapt to her husband's expectations and needs; any vices she had could still be corrected. They are often compared to wax, which, when still soft, can be moulded according to one's wish, but the marks already left in the hard wax (a widow) are almost impossible to erase (Barbaro, 1513, Book I, ch. III, 
also: Alberti, 1844, p. 161; Erasmus, 1526, p. 312-313) It was the father of a teenage girl who was responsible for choosing a candidate who should be similar to his daughter. He had to take into account the origin, customs, language and social status of his prospective son-in-law and try to train his daughter in such a way as to suit the preferences of her future husband (Guazzo, 1574, p. 159).

A well-behaved and obedient daughter was not allowed to leave her house too often or spend time in the company of men, however, once she became a teenager she had to remember that the opposite sex was going to attract her attention. A young, chaste woman should remember that she was not an equal speaking partner for a young man. Her life was focused on the house and everything that was connected with its everyday functioning, organisation and inhabitants; his — on everything but the house. They could not have too many things in common, and as a result their conversations were bound to be of a trifling nature and unbecoming to an innocent maid. However, if the situation forced them to talk, they should keep it short and simple and always with somebody else present. Playing, touching or kissing was never devoid of ambiguity and thus forbidden because they could easily enflame the young bodies and render the girl defenseless (Vives, 2000, pp. 130-132).

If a girl wanted to escape unwanted advances, she was advised to stop listening and simply walk away. If she decided to stay and engage in conversation, however, a man might take it as a sign that her heart could be won over with very little effort. Spending time alone with a man and secret caresses were unthinkable and, even if the girl did not lose her virginity, she might have lost her chastity (Bouchet, 1545, épistre X). A young girl should also remember that she should not accept compliments from men, especially the ones who did not refrain from alcohol, as their words could never be trusted (Le doctrinal..., 1492?, n. p.). She should also never give or accept gifts from the courting men since: "A woman who accepts, sells herself; a woman who gives, has given herself," (Vives, 2000, p. 130).

If a young girl could not find a husband without putting her chastity at risk (by taking part in banquets, spending time in the company of men, or wearing provocative clothes or make-up) she should have remained single and devoted her life to God. Otherwise, she would agree to marry the devil only to be later married to a man. Maids should only worry about two things: their unquestioned chastity and unblemished reputation - with these two things they could be certain of finding the right partner (Vives, 2000, p. 167).

When choosing a husband for their daughter, the parents did not have to take into account her feelings or preferences (Stone, 1965, p. 594). Furthermore, if she insisted on discussing her emotions, she would be regarded as ungrateful and immodest. Love was called the "poison of $[\ldots]$ scorpion" and once it entered the body, it turned the 
person blind and intoxicated everything on its way. A girl who did not want to suffer from this "Cupid's torch" should, from the very beginning be immune to the men trying to charm her. She should never trust their words and compliments, remembering that all they are after is her virginity (Vives, 2000, pp. 144-148). If, however, the girl gave in to temptation and fell in love, she should do everything in her power to quell that feeling and never forget that "present delights are momentary, torment is eternal". Fasting, praying, household chores and bringing to mind her lover's flaws should help her gradually root out the forbidden feeling. The maiden should also be aware that she is the source of sin for the man in love. Had she killed him, her guilt would have been smaller because she would have "only" doomed his body, not his soul. It was her responsibility to bring the man she had (even unknowingly) driven so crazy in love back to his senses. Vives supported his pieces of advice with an example of a woman from Barcelona who carried rotten cabbage leaves in her armpits to put off her insistent admirer (Vives, 2000, pp. 149-154).

Even if the girl had no idea who she was going to marry and often met her husband on the day of the wedding, her duty was to humbly accept her parents' decision. Usually she had no influence on their choice and the only thing she could do was to pray for a good husband. Even though the authors of the conduct books did not want to question the fact that daughters were obliged to obey their parents, they opposed the practice of marrying them off to the wealthiest candidates, comparing such a situation to a business transaction and the parents to the ruthless sellers: "they look only to riches, noble lineage, wealth and power in their son-in-law, things that will be to their own advantage, not what is best for their daughter, who must live with him within the same walls. These are enemies, not parents, or to put it more aptly, vendors of their own daughters, whom they sell for their own advantage," (Vives, 2000, p. 157; also Tyndale, 1528, pp. 204-205; Erasmus, 1526, p. 293). However, from the perspective of the head of the family, a daughter's marriage was a purely economic issue. The accumulation of a girl's dowry could bring the family to the brink of bankruptcy, but with a well-arranged marriage it might have been an investment for the future - creating new family connections or social advancement would one day pay off (Stone, 1965, pp. 594596). Furthermore, contrary to men, the social position of women was predetermined by the position of the family she was born into and she could do nothing to change it unless she married a man of a higher social status. If, however the girl had married a man of a lower social status she would have lost her position and could no longer transfer her titles to her offspring (Kelso, 1978, pp. 35-36; Erickson, 1993, pp. 99-152).

Because of the fact that the marriage knot could not be easily untied, caution and sensibility were recommended when choosing one's partner. The situation resembles a war, because in both cases the first mistake one made was also the last. (Erasmus, 
1526, p. 239) Among the reasons of why people are not happy as husbands and wives, the writers usually mentioned the fact that many of them, especially women, were forced to marry. The situation could be improved if the young people were allowed to decide for themselves or if their parents listened to their opinions, put themselves in their children's place and considered if they had wanted to spend their entire life with the person they had chosen for their daughter or son to marry (Guazzo, 1574, pp. 120-120a, also Vives, 2000, p. 157). However, the idea of love or closer relationship between the young people before they married was viewed as something deplorable. The girl who declares she is in love with the man before she marries him proves that she cannot be trusted because she may easily fall for somebody else as well, even if she is already married. What is more, if love has been kindled (usually by lust) before marriage it will probably burn out soon after it, as the saying goes: "Those who marry for love live in sorrow," (Vives, 2000, pp. 170-171). Even though there were many similarly pessimistic prognoses, some authors took the opposite view. They claimed that the ideal marriage should be based on the similarities - a husband and his wife should share similar behaviour, temperament and feelings, otherwise the two totally different people would never be able to live in harmony as one. It was also emphasised that before getting married the young people should get to know each other better and only if they decide they like each other, they can agree to be united in matrimony (Taillemont, 1576, pp. 139-140).

When marriage was concerned the conduct books usually contained a chapter devoted to the qualities a prospective wife or husband should have. The men were advised to focus on four aspects: age, wealth, social status and the beauty of the girl they were thinking of marrying (Kelso, 1978, pp. 80-83). Barbaro dedicates nearly the entire first volume of De re uxoria to this issue. For him, the most important aspect was the girl's character and her chastity. In order to illustrate his point, Barbaro (1513, Book I, ch. II) recounts two stories in which a man eventually chooses a girl who is well-born and has an unblemished reputation, but is poor. In the Renaissance, contracting marriage without the appropriate dowry was unthinkable, which is why marrying off daughters was often viewed as a business transaction. Being a member of the aristocracy himself, Barbaro tries to object to this procedure by underlining that what really should matter in choosing a wife is her good name and the willingness to take care of it. Guazzo (1574, p. 120) adds that the main reason of the marital discord is too many differences between the spouses, so when one should definitely focus on similarities when looking for the best candidate.

The second aspect on Barbaro's list was age (1513, Book I, ch. III; also: Alberti, 1844, p. 161) and the preference for young and inexperienced girls previously mentioned. However, some authors warned that if the age difference was too great (a wife 
who was either too young or too old) it might have a very negative effect and lead to quarrels between the spouses. According to them, it was also against nature (Guazzo, 1574, pp. 120-120a; also: Cholières, 1585, pp. 231-233). Ideally, a husband should be around 10 years older than his wife because such age difference makes it possible for a man and woman to mature and grow old at the same pace. Their sexual appetites would also diminish more or less at the same time. A 17 or 18-year-old girl and a man 10 years older would have a chance to build their relationship on mutual understanding and friendship (Marconville, 1573, pp. 35-35a).

The third factor, according to Barbaro, was aristocratic background. Using the metaphor of an orchard, the author explains that the best fruit is born by the plant with best seeds and in the best soil. The same happens with people — the best children are born by the noblest mothers. Only when two people of noble birth are married can the finest offspring be guaranteed (1513, Book I, ch. III). The family of the future wife is also important and should have been closely examined before any serious decisions were made. Alberti (1844, pp. 161-163) claims that he knows some men who preferred to remain bachelors because they would have never been able to come to terms with their prospective in-laws. It is thus reasonable that a man should find himself a wife whose relatives can behave well in various situations, are not boastful, know the meaning of hard work, and are not going to bring problems or debts on his own family. However, Erasmus (1526, p. 311) tried to warn the men that noble birth was not enough and that they should rather choose the girls who were well-behaved, not only well-born.

Another aspect discussed in the conduct books was the beauty of a future wife. Barbaro (1513, Book I, ch. V) declares that it is of so little importance that should not even be mentioned, but he adds that it can only be valued when it supplements other virtues which prove the noble nature of a woman. Physical beauty alone does not deserve any praises. Those men concerned with the beauty of their wives-to-be sooner or later have to face a dilemma: if he marries a beautiful woman, he will enjoy what he sees, but other men might pose some threat and enjoy the view as well; but if he marries a less beautiful woman, he will not take pleasure in looking at her, but he will not have to worry so much about potential rivals. The best solution was probably moderation and finding a wife who was average — beautiful enough to prevent the husband from looking at others, but ugly enough to let him sleep peacefully (Guazzo, 1574, pp. 122-123a). Cholières (1585, Matinée V) in his long dialogue on female beauty tries to refute the Plato's theory according to which a beautiful body must have a beautiful soul. The author claims that usually the most attractive people are the most vicious and that beautiful parents do not necessarily have beautiful children. What is more, having a beautiful wife does not guarantee fidelity because men, sooner or later, crave variety. 
Beauty is in the eye of the beholder and should not constitute a decisive factor in choosing a wife. Alberti (1844, p. 161), however, seems to be more pragmatic and claims that a girl should be neither too fat, nor too thin, but definitely should have wide hips as this is a certain proof of her fertility.

The last criterion on the Barbaro's list was wealth (1513, Book I, ch. VI; also: Taillemont, 1576, pp. 124-126). The author does not question the usefulness of money, but he recommends sensibility and moderation because, according to him, the young men are obsessed with the idea of becoming rich and the only thing they require from their future wife is a substantial dowry. The author attempts to protest against the above mentioned procedure of treating marriage as a business transaction, but a girl's dowry was an inseparable element of the marital tradition and a tangible input into the life of a new family. Additionally, the dowry was also a kind of security deposit in case a wife became a widow (Fairchilds, 2007, pp. 55-65; Wiesner, 2000, pp. 73-75; Hogrefe, 1975, pp. 12-16; Stone, 1977, pp. 97-99). Guazzo (1574, pp. 120a-121a) once again suggests moderation and sobriety. The woman's dowry should more or less equal the man's wealth. But if a man ignores his common sense and chooses a beautiful but poor wife, his life is going to turn into a series of problems and once the initial fascination has worn off, he will treat his wife as a mere servant. If a man does not resist the temptation and marries a woman who is wealthier than he, he needs to remember that she will probably treat him as a person inferior to her. The most important of a wife's duties is obedience and if she tries to use her wealth, social status or family name to take control and oppose her husband, she acts against the nature and breaks not only God's law but also the traditionally-established customs. So, if a man marries such a rich woman, his duty is to do anything he can to stop her from doing this (Tiraqueau, 1515, Lex I).

Dorothy Leigh instructing her sons on choosing the best wife summarises the advice with the statement:

[...] marry with none, except you loue her, and be not changeable in your loue; let nothing, after you haue made your choise, remoue your loue from her; for it is an vngodly and very foolish thing of a man to mislike his owne choise, especially since God hath giuen a man much choyse among the godly; and it was a great cause that mooued God to commaund his to Marry with the godly, that there might be a continuall agreement between them. (1622, pp. 52-53)

A Renaissance man looking for a wife was equipped with a wide range of advice which was supposed to make the choice easier. They provide us with a unique opportunity of having a closer look on what was expected of the young women who were about to get married. In case of women, the conduct books usually contain advice ad- 
dressed to their parents, especially to their fathers, who were responsible for choosing the best candidates (Vives, 2000, p. 291). In the chapter devoted entirely to the issue of finding a good husband for one's daughter, Vives criticises:

O stupid parents! O senseless and foolish girls who prefer handsome, rich, or noble spouses to good ones. You increase your cares, anxieties, and troubles, which a marriage brings with it of itself. Marriages based on money or sensual pleasure are disastrous, like that of Helen and Paris [...] If you marry a handsome man, his beauty will make him conceited; a rich man, his riches will make him contemptuous. Marry a nobleman, and his noble birth will make him insolent. (2000, p. 160)

When choosing the best candidate, the parents should pay attention not only to external but also internal factors. When analysing his appearance, they should take into account what he looks like, his age and health. Beauty fades with time and that is why it should not be the main criterion when choosing a husband. Also, even if the man is not handsome, he should not be disqualified because a flawed body may contain a beautiful soul. His age should be similar to her age — he cannot be too young because he will lack respect once he becomes the head of the family and he cannot be too old either because he will not be able to manage the household effectively and may soon turn his wife into a widow and his children into orphans. Good health seemed to be the most important because it enabled the man to perform his everyday duties and have healthy offspring. Still, the internal aspects should constitute the decisive factor:

This is the one criterion we should use. On this we must base our judgement of a man. There is nothing in physical attributes or material well-being that can provide us with a sure estimation of a man: not riches, possessions, race, power, influence, dignity, entourage, beauty, health, age, soundness of body, stature, nor their opposites - nothing, in a word, but his character, in which are to be found intelligence, learning and virtues, or their opposites: dullness, ignorance, and vice. (Vives, 2000, p. 159)

The girl should also remember that she can be a good wife only when married to a good husband. If the man who she has wed is evil, sooner or later she will become a bad person as well (Vives, 2000, pp. 159-160).

Contemporary youth was heavily criticised for seeking only earthly pleasures and riches. As a result, many girls got married to men who resembled "wild beasts" — without manners and ignorant of their duties. When choosing a husband for their daughter, fathers were advised to remember that "A bad son-in-law is and enemy, not a rela- 
tive. A good one is not so much a son-in-law as a son," (Vives, 2000, pp. 163-166, also: Agrippa, 1534, p. 75; Erasmus, 1529, pp. 842-855).

The husband's responsibility was to maintain his family, thus it was reasonable to make sure what the occupation of its future head is and whether his earnings come from a decent source. Vives (2000, pp. 158-159) lists the professions which are "dishonourable" and men performing them should be avoided: a usurer, executioner, pirate and mercenary soldier. A girl (or her parents) should also not consider marrying a shopkeeper or a go-between unless she is desperate and has no other option of finding a different livelihood, or is of the same class as the man. Cholières (1585, Matinée VIII) presents the qualities of the ideal husband in a dialogue which should help the girl decide if it is better to spend her life with an artist (serenity, knowledge, understanding, elegance, beauty, romanticism) or a soldier (strength, health, pragmatism, realism, order, honour).

However, once the choice was made and a candidate for the future husband was selected, the parents could not criticise or undermine his authority in any way. Taking into account the bond which usually connects a mother and her daughter, the mothers were warned that once their girl was married, she could not be treated the same way. The power and control over her was handed over to her husband and the mother should now regard her as an emigrant who went away to a faraway country and is going to bring up her own children. When talking to the newly-married daughter, the mother should take on the role of an advisor and help her live in harmony with her husband and his family (Vives, 2000, pp. 292-293).

In the conduct literature, there is one more aspect usually mentioned when it came to the marriage preparations - the wedding reception. Traditionally, it was to last the entire day and very often was accompanied by a series of indecent rites and customs. The two young people who had just got married had to spend their wedding day talking to and observing people engaged in excessive drinking, eating, dancing, flirting or even kissing. This was not a good lesson for the groom who had just decided to abandon his bachelor state or for the bride who was about to begin a virtuous life with her husband. Furthermore, the organisation of such a party required a great deal of money and often the families went bankrupt just to prove they could afford it. Instead of a bacchanalia, the wedding ceremony should be limited to the young couple going together to the church, taking the sacrament and being accompanied back home by the members of their closest family (Vives, 2000, p. 292; Erasmus, 1526, pp. 348-349). 


\section{Renaissance Marital Ideology}

Getting married was a turning point for both sexes, but in case of women the transformation from daughter into a wife modified almost every aspect of her daily life and presented her with new roles to play. It is clearly visible when one contrasts the image of an ideal Renaissance man - an articulate, talented, well-educated courtier — with that of an ideal Renaissance woman, who was not an elegant court lady, but a modest, married woman who embodied all the Christian virtues, stayed at home as much as possible and took constant care of her family (Kelso, 1978, p. 78). In the Middle Ages, it was the monastic way of life which was considered to be ideal, available only for a few "chosen" individuals. However, the humanists put aside medieval celibacy, mortifying oneself and serving God and instead gave priority to the institution of matrimony. Erasmus tried to explain why marriage became more important than the celibate life (1526, pp. 243-245) and Martin Luther claimed that marriage and maternity were inseparable elements of the female life cycle and if women voluntarily refrained from them, they acted against the divine order of things according to which a woman is always subjected to man. For him, the ideal woman was no longer Virgin Mary, but a wife and mother taking care of her house and her family (Wiesner, 1990, pp. 123-134).

The first texts of Erasmus from the beginning of the sixteenth century depicting the superiority of the married life such as In Praise of Marriage (1518) and The Institution of Christian Matrimony (1526) were initially heavily criticised but with time became the basis of Renaissance marital ideology. Quite surprisingly, The Institution was dedicated to Queen Katherine of Aragon, whose marriage to Henry VIII was supposed to set an example. Even though in his dialogues from 1523 (Courtship, The Girl with No Interest in Marriage, The Repentant Girl, Marriage) Erasmus thoroughly described the worst mistakes and the most common problems the married people face, in The Institution he attempts to present the ideal marriage. Even in his text on the Christian doctrine, An Explanation of the Apostles' Creed, when listing the sacraments he gives the first place to marriage rather than baptism (1533, p. 340).

Erasmus' fervent defence of marriage could be regarded as a reflection of his antimonastic attitude, but it was not the only message he tried to convey. First of all, he does not completely negate the benefits of living a celibate life, but only if such a decision was made voluntarily and had its roots in deep faith (1533, pp. 291-292; 1529, pp. 200-202). When it comes to marriage, Erasmus advises that it should be treated more seriously and people who are to be wed should think twice before doing so. It is easy to contract a marriage but not so easy to dissolve it (1526, pp. 240, 255, 275-278). Erasmus claims that marriage is valid only when it was contracted with the consent of the people who are to be married and their parents, and in the presence of witnesses (1526, 
pp. 118, 245-248, 293, 296). What he also suggests is that the institution of matrimony should be more "flexible" and take into account the flawed nature of humans, thus if all attempts to make the lawful marriage ultimately fail (even if the marriage has already been consummated), a divorce and even remarriage in the future should be considered (Payne, 1970, pp. 121-125; Margolin, 1999, pp. 37-66).

It was the religious reformation that introduced serious changes to the social perception and evaluation of marriage. Instead of celibacy it was the state of matrimony that was now given importance and became a model that should be imitated by pious Christians across Europe (Stone, 1977, p. 135; Rose, 1988, p. 3). One of the most significant changes was connected with the source of knowledge and advice on marriage and family life: celibate priests were replaced with married preachers who could support their teachings with their own experience. In Sermon X on Matrimony, Henry Bullinger, basing his reasoning mainly on the Bible, proves that matrimony is holy thus no man can be deprived of the right to be lawfully united with his spouse. When explaining the need to get rid of celibacy among the clergy he states:

[...] wedlock is holy, and that therefore no man can be defiled with the moderate, holy, and lawful use thereof and bidden to marry. Consequently, that marriage is permitted to all sorts of men. For the apostle saith: "Let a bishop be the husband of one wife; let him rule his own house well, and have faithful children." For it is manifest, by the testimonies of scripture and ecclesiastical writers, that the apostles of Christ and other apostolical teachers of the primitive church were married men, and had wives and children. Neither is there anything, next after corrupt doctrine, which doth more infect the church of Christ, and subvert all ecclesiastical discipline, than if the ministers of the churches, which should be lights of the whole congregation, be fornicators or adulterous persons. (Bullinger, 1849, p. 402)

Even though the situation changed, there was no single Protestant or even Puri$\tan$ model of the ideal marriage and family life. The Protestant doctrine adopted the Catholic teachings regarding marriage and modified them to suit its needs (Crawford, 1996, p. 22). The most valuable sources of Protestant ideas on marriage and family can be found in catechisms popular at that time, sermons preached in churches (e.g. A Preparative for Marriage by Henry Smith in 1591) or advice books dedicated directly to women. The Catechism by the religious reformer Thomas Becon was one of the first Protestant advice books written in English which helped spread the new ideas among the common people. It was written under Edward VI, but was published once Becon's position at court had been restored (after Mary I's reign) under Elizabeth I. The language was deliberately made simple and the entire text consists of a dialogue between a father and his son. Even though numerous pieces of advice concern women - mo- 
thers, daughters or widows - it is only men who converse. Still, one of the most comprehensive texts of this genre was written by William Gouge in 1622 and is entitled Of Domestical Duties. The author meticulously portrays the rules according to which a Protestant family should be organised and the duties of each family member. What is worth underlining is the fact that, apart from the still valid hierarchy (father-motherchildren) and the patriarchal belief that a father "is a King in his own house" (2006, p. 183), Gouge promoted the idea of a "companionate marriage" where a wife is not only a passive, obedient subject but almost an equal companion, partner and a friend who can help, give advice and console if needed. Also, the importance of love, which should be openly expressed by husbands, is something innovative and cannot be easily found in the sixteenth-century texts for women:

His look, his speech, his carriage, and all his actions, wherein he hath to do with his wife, must be seasoned with love: love must shew itself in his commandments, in his reproofs, in his instructions, in his admonitions, in his authority, in his familiarity, when they are alone together, when they are in company before others, in civil affairs, in religious matters, at all times, in all things: as salt must be first and last upon the table, and eaten with every bit of meat, so must love be first in an husband's heart, and last out of it, and mixed with every thing wherein he hath to do with his wife. (2006, p. 249)

When it comes to sermons, the compilation called Certain Sermons or Homilies to Be Read in Churches published for the first time in 1547 deserves recognition. 33 sermons divided into two volumes (the second of which was finished under the reign of Elizabeth I) present the doctrine of the reformed Anglican Church in a more detailed and reader-friendly way (in English, simple language) than the Thirty Nine Articles of Faith (The Oxford Dictionary of the Christian Church, 2005, pp. 790, 1622). In Sermon XVIII (Book II) on marriage (1864, pp. 534-549), the initial definition is followed by a text infused with practical tips that were supposed to help wives and husbands in playing their roles well. Generally, in order to thwart the "Satan's plan" to ruin their relationship, the married couple should avoid quarrels and pray often. The woman is depicted as weaker and more fragile thus requiring special treatment - she can be motivated to fulfil her duties more by praises than by criticism or blows. Among the virtues which a married woman should possess unquestioning obedience takes the first place, along with humility and modesty. The marriage will be successful only when spouses have one heart, similar minds and work together for the benefit of their family.

If one was to summarise the main aspects of the Protestant teachings on matrimony and family life, the list would consist of elements such as: being married was not only a substitute of being celibate, it had value in itself; a man and wife should love and 
respect each other and try to solve the problems together ("companionate marriage"), but it is the husband who is the head of the family and he is charged with taking care of its spiritual development (reading the Bible, leading prayers, etc.); the wife should obey her husband but if she makes a mistake or happens to fail in her duties, she should not be punished; marriage was instituted by God and its main aim was to provide lawful children, thus both marriage and maternity were seen as integral elements and stages of a woman's life; carnal love was recognised as an important factor in strengthening the marital bonds and preventing the spouses from adultery, but it should be done in accordance with the idea of a "chaste marriage" combining fidelity, moderation, consent and willingness (Fletcher, 1994, pp. 161-181).

When comparing the Catholic and Protestant doctrines on marriage, one notices that apart from the depreciation of celibacy and making divorce and remarriage more accessible, there are no significant differences between them. Both Catholic and Protestant sermons contained similar advice for wives and husbands and in the exactly same way defined the ideal, patriarchal pattern of the family, where the father occupies the most important place and governs his miniature "kingdom" (Davies, 1981, pp. 58-80; also: Lucas, 1990, p. 224). According to this theory, a country can function well only if the people are subjected to their ruler, and a marriage can be successful only if a wife and children are subjected to their master — the husband/father. The way a family is organised should resemble the organisation of a country - in both cases the male is superior and has to be listened to and obeyed (Cott, 2002, p. 12; Peters, 2004, pp. 7 , 12). Even in Shakespeare's The Taming of the Shrew one can find the literary traces of this ideology:

Such duty as the subject owes the prince

Even such a woman oweth to her husband;

And when she is froward, peevish, sullen, sour,

And not obedient to his honest will,

What is she but a foul contending rebel

And graceless traitor to her loving lord?

I am ashamed that women are so simple

To offer war where they should kneel for peace;

Or seek for rule, supremacy and sway,

When they are bound to serve, love and obey.

(Act V, Scene II)

There was one more popular Renaissance theory originally taken from Plutarch: a married woman should be like a mirror which reflects her husband's moods, habits 
and problems. The ideal wife somehow loses the possibility to express her own emotions because whatever she does, thinks or says should be adjusted to the husband's frame of mind and way of life. When looking at his wife, a man should see nothing more but himself (Wayne, 1996, p. 69). Both Erasmus (1526, p. 341) and Sir Edmund Tilney, a courtier of Elizabeth I, used the mirror metaphor to illustrate one of the most important virtues every wife should possess - subjection. In Tilney's Flower of Friendship, originally written in 1568, it is Ladie Julia who explains the duties of a good wife (1992, p. 138): "Sheeshal enlarge the Flower of Friendship between hir and hir husband, whose face must be hirdayile looking glasse, wherein she ought to be alwaies prying, to see when he is merie, when sad, when content, and when discontent, whereto she must alwayes frame hirowne countenance." Even though Tilney supported the idea of a "companionate marriage", the mirror metaphor he uses equals to women not having the right to show what and how they really felt. Their emotional life was believed to be uninteresting and unimportant, and it was she who should conform, adjust and obey. Even though a wife could treat her house as her kingdom within which she could present her virtues and qualities, she could not forget that she was just a mere moon which shines and radiates the light it reflects rather than its own (Kelso, 1978, p. 78), In Philosophisch Ehruchtbüchlein (The Book of Marital Discipline) from 1578, Johann Fischart of Strasburg explained:

Let man be like the sun

And woman like the moon.

The sun does have a brighter shine,

But the moon has its shine, too.

And just as the sun does not destroy

The radiance of the moon, but magnifies it:

An upright man should honor his woman,

For honor, after all, is shared,

Just as material goods do not belong to one alone:

And where such community is not preserved,

And every light does not preserve its glow,

It could not survive:

It would be as though the sun repudiated the moon,

Or the moon the sun.

(quoted in Wunder, 1998, p. 206) 


\section{The Definition of Marriage}

As it has already been described, in the Renaissance the institution of matrimony was still regarded from the very traditional, Christian perspective according to which it was God who joined a man and woman into one body, mind and will, with the consent of those who were to be married and those who were responsible for them (Kelso, 1978, p. 78). Erasmus (1526, p. 219) defined it as: "a lawful and perpetual union between a man and a woman, entered for the purpose of begetting offspring, and involving an indivisible partnership of life and property." What is more, the Church also emphasised the fact that getting married is the best way to avoid fornication (remedium propter fornicationem). Saint Paul's words from his First Letter to the Corinthians (7:9) "For it's better to marry than to burn" became the biblical basis of the belief that being married is a relatively pious way of life whose main aim is to prevent licentiousness. Apart from its religious function clearly defined by canon law, the institution of matrimony had also important economic ("selling" daughters to the richest candidates or attracting the candidates from influential families by substantial dowries) and social (social advancement if the girl was married to a man of a higher social status) roles which are reflected by the customs and traditions of those times. The religious and lay models of marriage could be compared to the theory and practice: the Church, wanting to control human sexuality, provided the theological bases, but the customs in use, seemingly in agreement with the catholic teachings, were to secure the lawful offspring and relieve sexual tension in a decent way (Duby, 1977, p. 20).

The above mentioned Protestant sermon on matrimony begins with its detailed definition:

The word of Almighty God doth testify and declare whence the original beginning of matrimony cometh, and why it is ordained. It is instituted of God, to the intent that man and woman should live lawfully in a perpetual friendly fellowship, to bring forth fruit, and to avoid fornication: by which means a good conscience might be preserved on both parties in bridling the corrupt inclinations of the flesh within the limits of honesty; for God hath straitly forbidden all whoredom and uncleanness, and hath from time to time taken grievous punishments of this inordinate lust, as all stories and ages hath declared. Furthermore, it is also ordained, that the Church of God and his kingdom might by this kind of life be conserved and enlarged, not only in that God giveth children by his blessing, but also in that they be brought up by the parents godly in the knowledge of God and true religion might be delivered by succession from one to another, that finally many might enjoy that everlasting immortality. (p. 534) 
Vives declared that "marriage is a knot that cannot be untied" and also underlined two aspects that should be well though over before one decides to get married: living together and offspring (2000, pp. 157-158). For the author, "living together" meant taking care of the welfare of the family, its material sustenance, health and spiritual development, which might be difficult to achieve if there were too many differences between a man and his wife because "likeness is the tightest bond of love". Also, according to Erasmus (1526, p. 302), "A marriage cannot be successful unless harmony reigns in it, and harmony comes from similarity of temperament and character and from mutual good will."

Vives also tried to explain why God instituted marriage. Referring to the Bible he claimed that once God had created a man, he did not want to let him live his life alone so he created a companion for him - a woman: "So he joined to him a living partner, like to him in mind and body, with whom he could associate, converse, and spend his life suitably and agreeably; and finally, provide for the procreation of offspring, if he so desired." By bringing woman to man God indicated who should be subjected to whom and why the union is being created (Vives, 2000, p. 175).

The possibility of having lawful children (sons especially) who would continue the family line was obviously one of the most pragmatic reasons of contracting marriage. However, in the first half of the sixteenth century some Catholic theologians had already abandoned the medieval Augustinian belief that the sole purpose of marital intercourse is begetting offspring (Noonan, 1966, pp. 312-313). As a result there are many traces, not only in the conduct literature, of the Renaissance idea of a "companionate marriage" which was contracted to serve also other purposes and not only legalising wantonness (Schnucker, 1980, p. 77). The scope of "partnership" is now difficult to define, but definitely the "companionate marriages" allowed women to assume other roles than only those of mothers and wives (Turner, 1987, ch. III).

Even though, theoretically a marriage was supposed to be a union of the two equally important individuals, in practice a husband and a wife had totally different roles to play. From the male perspective, getting married guaranteed stable, regular life, the respect inseparably connected with the office of a husband, new family connections, lawful children and help and support of a well-chosen wife:

Thus, in brief, a gentleman on marrying will seek to form and maintain an establishment that will promise him as stable a life as man may hope for in this world, under as advantageous conditions as may be, to enable him to play the part in society fitted to his birth, talents, and connections. In this unequal partnership of marriage he holds the dominant place, and bears the ultimate responsibility. (Kelso, 1978, p. 90) 
In order to convince a man to get married, the advice books mentioned the respect and esteem connected with being the head of the family and everyday benefits of having a good wife (Vives, 2000, p. 328). To convince a girl — from her very early years she was made to believe that being a wife and mother was her destined lot, so getting married should be treated as her duty and the most important goal. However, instead of encouragements, she was constantly given warnings about the problems awaiting her in her married life. Furthermore, she was made responsible for the success of her marriage. By being virtuous and acting in the right way she could make the family happy and harmonious, but if she let her vices take over, misery would have never left her household:

You will be a maidservant in eternal drudgery; you will work, pull the millstone, cry, be afflicted; you will curse the day you were joined to him in the marriage bed, the day on which you were born, and your parents and relatives and whoever else had a hand in arranging such a marriage, if by your vices you offend your husband and inspire his hatred. But you will be mistress of a happy household, you will be happy, exultant, and will bless the day you were married and those who joined you to him if by your virtues, modesty, and compliance you render yourself lovable to him. (Vives, 2000, pp. 176-177)

She should seek consolation in the fact that from the day she got married, the woman would have one body, one mind, one table and one bed with her husband, upon whose company, support and love she could count till the end of her days (Vives, 2000, p. 172).

Summing up, marriage in the sixteenth century was an important and widely discussed social issue. With the arrival of Protestantism it ceased to be a sacrament, but gained importance as the basic unit of the social structure. Renaissance women did not have to remain virgins to climb up the ladder to perfection. Quite the contrary, it was now the wife who was perceived as the ideal, thus getting married became the most natural and a highly recommended thing. The conduct literature for women brims with advice on theoretical and practical aspects of the institution of matrimony and provides us with a unique opportunity of having a closer look at what the idealised image of getting and being married in the sixteenth century was. Knowing what marriage is and what it entails, preparing oneself and seeking the best candidate was a challenging task, and the girls of those time might have been in need of advice. However it was the moment of becoming a wife that turned their lives upside down, imposed new duties and responsibilities and gave a totally new role to play. It can be well illustrated by a prayer of a young married woman, written probably by her (found in Bentley's anthology of 
religious texts written mainly by women and dedicated to women), in which she asks God to help her perform her marital duties in the best possible way:

O Lord, forasmuch as thou of thy fatherlie goodnes hast vouchsafed to keepe me from my tender age untill this present, and hast now called me from my single life, unto the holie state of honorable wedlock, that I living therein, might according to thine ordinance, bring forth children unto thy glorie, give me grace I most entirelie beseech thee, to walke worthie of my vocation, to knowledge my husband to be my head, to be subiect unto him, to learne thy blessed word of him, to reverence him, to obeie him, to please him, to be ruled by him, peaceablie and quietlie to liue with him, to weare such apparell as is meet for my degree, and by no meanes to delight in costlie iewels, and proud gallant vestures; but alwaie to vse such cloathing, as becommeth a sober, chast, and christian woman, circumspectlie and warelie to looke to my houshold, that nothing perish through my negligence; and alwaies haue a diligent eie, that no dishonestie, no wickednesse, vngodlinesse be committed in my house, but that in it all things be ordered according to thy holie will, which art worthie all honour, glorie and praise for euer and euer, Amen. (Bentley, 1582, p. 68)

\section{Bibliography}

\section{Primary sources:}

Agrippa, Henricus Cornelius. (1534). The Commendation of Matrimony, made by Cornelius Agrippa, translated into englysshe by Dauiid Clapam. Trans. D. Clapam. London.

Alberti, Leon Battista. (1844). Quattro libri della famiglia. In A. Bonucci (ed.), Opere Volgari di Leon Battista Alberti, vol. 2. Firenze: Tipografia Galileiana.

Barbaro, Francesco (1513). Francisci Barbari patricii Veneti oratorisque clarissimi de re Uxoria libelli duo, Paris: in aedibus Ascensianis.

Barberino, Francesco da (1842). Del reggimento e de'costumi delle donne di messer Francesco da Barberino Pubblicato per cura di Guglielmo Manzi Romano, Milano: Giovanni Silvestri, [reprint].

Becon, Thomas (1844). The Catechism of Thomas Becon with other pieces written by bim in the reign of king Edward the Sixth. Ed. J. Ayre. Cambridge: The Cambridge University Press.

Bouchet, Jean (1545). Épîstres morales et familières du Traverseur, Poictiers: Jacques Bouchet et Jehan et Enguilbert de Marnef.

Bullinger, Henry (1849). The Decades of Henry Bullinger, Minister of the Church of Zurich, Translated by H. I. The First and Second Decades. Vol. 1. Ed. rev. T. Harding, A. M. for the Parker Society. Cambridge: Cambridge University Press, [reprint form 1577].

Cholières, Nicolas de (1585). Les Neuf Matinées du Seigneur de Cholières. Dediees à Monseigneur Vendosme, Paris: Chez Iean Richer, rue sainct Iean de Lateran, l'enseigne de l'arbre Verdoiant.

Desiderius, Erasmus (1529). A Marriage in Name Only or The Unequal Match. Trans. Louis A. Perraud. In J.W. O’Malley (ed.) (1998). Collected Works of Erasmus: Colloquies, vol. 40 (pp. 842 859). Toronto-Buffalo-London: University of Toronto Press. 
Desiderius, Erasmus (1533). An Explanation of the Apostles' Creed. Trans. Louis A. Perraud. In J.W. O’Malley (ed.) (1998). Collected Works of Erasmus: Spiritualia and Pastoralia, vol. 70 (pp. 231-388). Toronto-Buffalo-London: University of Toronto Press.

Desiderius, Erasmus (1529a). On the Christian Widow. Trans. J. Tolbert Roberts. In J.W. O’Malley \& J. Tolbert Roberts (eds.) (1998). Collected Works of Erasmus: Spiritualia, vol. 66 (pp. 177258). Toronto-Buffalo-London: University of Toronto Press.

Desiderius, Erasmus. The Institution of Christian Matrimony (1526). Trans. M.J. Heath. In J.W. O’Malley \& L.A. Perraud (eds.) (1999). Collected Works of Erasmus: Spiritualia and Pastoralia, vol. 69 (pp. 203-438). Toronto: University of Toronto Press.

Gouge, William (2006). Of Domestical Duties. Ed. G. Fox. Morrisville: Lulu.

Guazzo, Stefano (1574). La civil conversatione del Signor Stefano Guazzo, Gentibuomo di casale di Monferrato. Divisa in quattro libri. Nel primo si tratta in generale de' frutti, che si cavano dal conversare, \& s'insegna a conoscere le buone dalle cattive conversationi. Nel secondo si discorre primieramente delle maniere convenevoli a tutte le persone nel conversar fuori di casa, \& poi delle particolari, che debbono tenere conversando insieme i giovani, \& i vecchi; i nobili, \& gl' ignobili; i prencipi, \& i privati; i dotti , \& gl' idioti; i cittadini, \& i forestiere; i religiosi \& secolari; gli huomini, \& le donne. Nel terzo si dichiarano particolarmente i modi, che s'hanno a serbare nella domestica conversatione; cioé tra marito, \& moglie; tra padre, \& figlivolo; tra fratello, \& fratello; tra patrone, \& servitore. Nel quarto si rappresenta la forma della civil conversatione, con l'essempio d'un convito fatto in casale, con l'intervenimento di dieci persone. Vinegia: Enea de Alaris.

An Homily of the State of Matrimony (1562). In Certain Sermons or Homilies Appointed to Be Read in Churches in the Time of the Late Queen Elizabeth of Famous Memory. (1864). London: Printed for Promoting Christian Knowledge, Sold at the Depository, Great Queen Street, Lincoln's Inn Fields, 4 Royal Exchange, 16 Hanover Street, Hanover Square, and By All Booksellers, pp. 534-549, [reprint].

Le doctrinal des filles, Angoulême, 1492?, not paginated.

Leigh, Dorothy (1622). The mothers blessing: or, The godly Counsaile of a Gentle-woman, not long since deceased, left behind for her children: Contayning many good exhortations, and godly admonitions profitable for all Parents, to leane as a Legacy to their children. By Mris. Dorothy Leigh, Printed at London for Iohn Budge, and are to be sold at his shop, at the Greene Dragon in Pauls Churchyard.

Marconville, Jean de (1573). De l'heur et malheur de mariage; Ensemble les Loix connubiales de Plutarque traduictes en Francois, Par Iean de Marconville Gentilhomme Percheron, reven \& augmenté. Lyon: Par Benoist Rigaud.

A praier to be said of a yong married woman, or, a Wife. (1582) In T. Bentley (ed.), The Fift Lampe of Virginite: Conteining sundrie forms of christian praiers and meditations, to bee used onlie of and for all sorts and degrees of women, in their seuerall ages and callings; as namelie, of Virgins, Wiues, Women with child, Midwines, Mothers, Danghters, Mistresses, Maids, Widowes, and old women. A Treatsie verie needful for this time, and profitable to the Church: now newlie compiled to the glorie of God, \& comfort of euer woman distressed in child birth or other wife. London: H. Denham.

Taillemont, Claude de (1576). Discours des champs faez a l'honneur et exaltation de l'Amour et des Dames, Par C. de Taillemont, Lyonnois. Lyon: Par Benoist Rigaud.

Tilney, Edmund (1992). The Flower of Friendship. A Renaissance Dialogue Contesting Marriage. Ed. V. Wayne. Ithaca-London: Cornell University Press.

Tiraqueau, André (1515). Andreae Tiraquelli Fontiniacensis judicis ex commentariis in Pictonum consuetudines sectio de Legibus connubialibus: diligenter recognita \& tersa erasis videlicet spurcitiis nuper per dolum frauenmque insertis, Vaenemdatur rursus in aedibus Ascensianis. 
Tyndale, William (1528). The obedience of a Christen man, and how Christen rulers ought to governe, wherein also (if thou marke diligently) thou shalt find eyes to perceave the craftie conveyaunce of old jugglers. Set forth by William Tyndale. Antwerp, [reprint]. In T. Russel (ed.) (1831). The Works of the English Reformers: William Tyndale and John Firth, vol. 1 (pp. 163379). London: Ebenezer Palmer.

Vives, Juan Luis (2000). The Education of a Christian Woman, a sixteenth-century manual. Ed., trans. Ch. Fantazzi. Chicago-London: The University of Chicago Press.

\section{Secondary sources:}

Abbott, M. (1996). Life Cycles in England 1560-1720. Cradle to Grave. London-New York: Routledge.

The Books of Homilies. (2005). In F.L. Cross \& E.A. Livingstone (eds.), The Oxford Dictionary of the Christian Church ( $3^{\text {rd }}$ ed. rev.) (p. 790). Oxford: Oxford University Press. https://doi.org/ 10.1093/acref/9780192802903.001.0001.

Chojnacki, S. (2000). Measuring Adulthood: Adolescence and Gender. In Women and Men in Renaissance Venice. Twelve Essays on Patrician Society (pp. 185-205). Baltimore and London: The John Hopkins University Press.

Cott, N.F. (2002). Public Vows: A History of Marriage and the Nation. Cambridge, MA: Harvard University Press.

Crawford, P. (1996). Women and Religion in England 1500-1720. London: Routledge.

Duby, G. (1977). Le marriage dans la société du haut moyen âge. In Ch. Verlinden et al. (eds.), Il matrimonio nella società altomedievale (pp. 15-39). Spoleto: Panetto \& Petrelli.

Erickson, A.L. (1993). Women and Property in Early Modern England. London: Routledge.

Fairchilds, C. (2007). Women in Early Modern Europe 1500-1700. Edinburgh: Pearson Education.

Fletcher, A. (1994). The Protestant Idea of Marriage in Early Modern England. In A. Fletcher \& P. Roberts (eds.), Religion, Culture and Society in Early Modern Britain. Essays in Honour of Patrick Collinson (pp. 161-181). Cambridge: Cambridge University Press. https://dx.doi. org/10.1017/CBO9780511585708.009.

Hogrefe, P. (1975). Tudor Women: Commoners and Queens. Ames, IA: The Iowa State University Press.

Kelso, R. (1978). Doctrine for the Lady of the Renaissance. Urbana and Chicago: University of Illinois Press.

Lucas, V.R. (1990). Puritan Preaching and the Politics of the Family. In Anne M. Haselkorn \& Betty S. Travitsky (eds.), The Renaissance Englishwoman in Print. Counterbalancing the Canon (pp. 224-240). Amherst: University of Massachusetts Press.

Margolin, J.-C. (1999). La conception érasmienne du veuvage et du remariage. Rinascimento, vol. 39, Firenze: L. S. Olschki, pp. 37-66.

Noonan, J.T. Jr. (1966). Contraception: A History of Its Treatment by the Catholic Theologians and Canonists. Cambridge, MA: The Belknap Press of Harvard University Press.

Payne, J.B. (1970). Erasmus: His Theology of the Sacraments. Richmond, VA: John Knox Press.

Peters, Ch. (2004). Women in Early Modern Britain 1450-1640. New York: Palgrave Macmillan Ltd.

Rose, M.B. (1988). The Expense of Spirit: Love and Sexuality in English Renaissance Drama. Ithaca, NY: Cornell University Press.

Stone, L. (1965). The Crisis of the Aristocracy, 1558-1641. Oxford: Clarendon Press.

Stone, L. (1977). The Family, Sex and Marriage in England 1500-1800. London: Weidenfeld and Nicolson. 
Thirty-Nine Articles. (2005). In F.L. Cross \& E.A. Livingstone (eds.), The Oxford Dictionary of the Christian Church ( $3^{\text {rd }}$ ed. rev.) (p. 1622). Oxford: Oxford University Press. https://doi.org/ 10.1093/acref/9780192802903.001.0001.

Turner, J.G. (1987). One Flesh: Paradisal Marriage and Sexual Relations in the Age of Milton. Oxford: Clarendon Press, chapter III.

Wayne, V. (1996). Advice for Women from Mothers and Patriarchs. In H. Wilcox (ed.), Literature in Britain 1500-1700 (pp. 56-80). Cambridge: Cambridge University Press.

Wiesner, M.E. (1990). Luther and Women: The Death of Two Marys. In A. Loades (ed.), Feminist Theology: A Reader (pp. 123-134). Louisville, KY: Westminster John Knox Press.

Wiesner, M.E. (2000). Women and Gender in Early Modern Europe. Cambridge: Cambridge University Press.

Wunder, H. (1998). He is the Sun, She is the Moon. Women in Early Modern Germany. Trans. T. Dunlap. Cambridge, Mass.: Harvard University Press.

Youings, J. (1984). Sixteenth-century England. London: Allen Lane. 